\title{
An Illusory March towards Equality between Women and Men
}

"Biographical Availability" and Career Inequalities Among Flight

Attendants

\section{Anne Lambert and Delphine Remillon}

Translator. Nicholas Sowels

\section{(2) OpenEdition}

\section{Journals}

Electronic version

URL: http://journals.openedition.org/travailemploi/10039

DOI: 10.4000/travailemploi.10039

ISSN: 1775-416X

\section{Publisher}

DARES - Ministère du Travail

\section{Printed version}

Date of publication: 1 March 2020

Number of pages: $85-120$

ISSN: 0224-4365

\section{Electronic reference}

Anne Lambert and Delphine Remillon, "An Illusory March towards Equality between Women and Men", Travail et Emploi [Online], Hors-série | 2020, Online since 01 March 2021, connection on 30 April 2021. URL: http://journals.openedition.org/travailemploi/10039; DOI: https://doi.org/10.4000/travailemploi. 10039 


\title{
An Illusory March towards Equality between Women and Men
}

\section{"Biographical Availability" and Career Inequalities Among Flight Attendants}

\author{
Anne Lambert, ${ }^{* *}$ Delphine Remillon ${ }^{* * * *}$
}

This article offers a comparative analysis of the careers of men and women flight attendants in air transport. Using personnel records, collective agreements and interviews with flight attendants, we show that the picture of improvements in career equality in the airline studied here is illusory. For earlier cohorts, the massive prevalence of women as flight attendants has been accompanied by growing access to positions of in-flight responsibility (cabin manager) and on the ground (base manager), while repeated cross-sectional data indicate a narrowing of the gap between men and women in entry and exit conditions over time. However, our longitudinal analysis of a cohort of flight attendants who entered the company more recently (between 1998 and 2001) reveals gender inequalities in the likelihood of promotion, to the disadvantage of women. Career models are also highly gendered, with women notably more likely to work part-time. Rather than countering this tendency, the shift from a system of promotion based on seniority to one based more "on choice" reinforces gender inequalities, contrary to the claims associated with the equal-opportunity policy implemented by the airline, as of the early 2000s. This is because the new system is more heavily based on employees' investment in the company throughout their careers, and thus on "biographical availability", which is greater among men than women.

\footnotetext{
* Traduction: Nicholas Sowels. Article published in French in Travail et Emploi, no 154, 2018.

This research is part of the collective NetWork-CAGE project on "Careers, Generations, Entourage. An Analysis of Professional Careers, Mobility and the Relationship to Work for Women and Men", which received financial backing from NetWork supported by heSam University (ANR-11-IDEX-0006-02) and from GIS Genre. We thank the participants and discussants of the study day organised as part of this project, in particular Sophie Pochic and Alban Jacquemart, two anonymous referees, and the Editorial Board of Travail et Emploi for all their comments and suggestions. Our thanks also go to Maxime Lescurieux, Élodie Baril and Marc Thévenin (INED) for their help in the initial processing of the databases and for their methodological advice. The usual disclaimer applies.

** Institut national d'études démographiques (INED), F - 93300 Aubervilliers, France; Centre Maurice-Halbwachs (CMH); anne.lambert@ined.fr.

*** Institut national d'études démographiques (INED), F - 93300 Aubervilliers, France; Centre d'études de l'emploi et du travail (CEET), LiRIS, U. de Rennes; delphine.remillon@ined.fr.
} 
$\mathrm{C}$ areer inequalities between women and men are increasingly well-documented. While vertical and horizontal occupational segregation mechanisms limit women's chances of promotion (MARry, 2004; LAUfER, 2005; GuILlaume, Pochic, 2007), the concept of gendered organizations (ACKER, 1990; MILLS, TANCRED, 1992) has recently made it possible to emphasize the role of work organizations in the production of these inequalities (ACKER, 1990; ANGElOFF, LAUfER, 2007; BusCATTO, MARRY, 2009). Masculine standards, often presented as neutral, structure employees' relationship to work, frame careers and govern promotions (DUNEZAT, 2006). Transport professions appear to be emblematic of such gendered organizations. They are largely embodied by male professional groups, such as merchant navy officers, train controllers or truck drivers (Guichard-Claudic, 2006; Rodrigues, 2010; BonAnNo, 2014), and have experienced limited feminization, being perceived as not very compatible with the roles of mother and wife because they require extensive "biographical availability" (MCADAM, 2012) on the part of their employees.

The expression "biographical availability" stems from work in political sociology on mobilizations and activist engagement (SIMÉANT, 2001; BARRAULT-STELLA, 2014). It provides a way of understanding how individual and private situations structure public engagement in changing institutional contexts (MCADAM, 2012). The term thus initially designated "the absence of personal constraints which increase the costs and risks of participating in social movements, such as a full-time job, a marriage or a family" (McADAM, 1986, p. 70). In this article, we propose using this notion in a dynamic and constructivist perspective, to analyze the way in which the family and professional lives interact, conditioning career development and career advancement over time. From our point of view, biographical availability does not constitute a simple objective indicator of the quantity of time available after deducting family and household commitments: it is not a substantial factor. On the contrary, it is produced by institutional context, in this case, work organization, by the formal rules which govern career development, and by the implicit standards which help to define a "good" commitment to work, which is in fact eminently gendered.

Paradoxically, the sociology of work has made little use of this analytical tool, despite the importance of research into professional commitment. Feminist sociologists who are interested in the balance between the "two-lives" of women as mothers and as employees have emphasized its effects on women's mental load and psychological suffering. Yet they have analyzed less its effects on the development of professional careers (HAICAULT, 1984). The notion of the "time availability for work" (BOUFFARTIGUE, 2012) most closely resembles that of biographical availability. But it aims to analyze the subordination of human time to professional time from a socio-historical, global and critical perspective (THOMPSON, 2004). If the duration, flexibility and predictability of working time - produced by productive structures and the law - condition employees' labor supply (their "working time availability"), then such supply takes different forms according to workers' places in the division of labor. The understanding of gender differences remains sketchy, however, as 
shown by the following remark by Paul Bouffartigue (2012, p. 9): "Flexible but autonomous workers are mainly highly-qualified men; the flexible, heteronomous employees are mainly women from working-class backgrounds [...] and female immigrant workers".

Some empirical research has specifically sought to objectify the time availability of women and men at work. While women's time availability appears shorter than men's at the start of their careers - in particular because of family responsibilities - it also takes different forms (fragmented working hours versus long hours and night work). Moreover, women's work suffers from less recognition by employers in terms of pay (DEVETTER, 2006). However, François-Xavier DEVETTER notes the difficulty in measuring the long-term effects of time availability at work on career development, due to the absence of longitudinal data on working time. This is precisely what analysis of personnel records, backed by interviews have allowed us to do (Box 1), by comparing the careers of women and men in the same profession, subject to similar hourly schedules.

The comparative analysis of the careers of hostesses and stewards in air transport is based on a relational approach to gender in the professional and family spheres. It is interesting from several points of view. Air hostesses make up two thirds of cabin crew. They exercise a profession that is classified in a category of employees, in France's nomenclature of professions and socio-professional categories (PSCs), and which is based on "naturalized female skills": the reception of passengers on board planes, the serving of meals and snacks, care and first aid, but also diffuse empathy towards clients (HochsCHILD, 2017 [1983]). At the same time, the working conditions of the cabin crew are characterized by large geographical displacements implying a chronic level of time and distance away from home (nights spent away), and by a de-synchronization of ordinary social rhythms linked to time changes, night flights, the seasonality of work, as well as to the irregularity of the schedules. ${ }^{1}$ In the company studied here, working hours, which are subject to France's Transport and Civil Aviation Codes, are thus defined by collective agreements negotiated every three years. The hostesses and stewards are "immobilized" twelve days per month (for a full-time contract), and fly in cycles of one to six consecutive days, depending on the geographic sector (short, medium or long-haul). The maximum working time is set at 92 hours per month, but the cabin crew members' activity schedules vary from month to month, depending on the needs of the company.

1. Compared to other transport professions, work in air transport also has its own constraints - jetlag and altitude which are physically disruptive and affect, for example, fertility. The company studied has in fact implemented working time arrangements for women engaged in a medically assisted reproduction program. 


\section{Box 1}

\section{The Survey and Material Used}

The monographic study of a major French airline allowed two types of material to be collected between 2014 and 2016, on which this article is based:

(1) The personnel records of cabin crew members (CCMs) were made available under a specific research agreement. They included all the CCMs working in the company between 1998 and 2015: after recoding and selection of the sample, nearly 25,000 people were identified as being present for at least one year between 1998 and 2015, of which around 14,000 people joined the company during this period. Constructed from the extraction, sifting and recoding of these records, the resulting CCM database made it possible to study career development in the company, within a relatively stable institutional perimeter (especially after the integration of another company). The variables available were socio-demographic (gender, age, number and date of birth of children), and related to employees' careers in the company (rank, geographical sector of assignment [long or medium-haul], type of contract [full or part-time] and working hours, date and reason for terminating a contract, age at entry and type of contract on entry). These records are produced for personnel management purposes, and do not contain any information relating to employees' professional or personal situation before entering the company, such as their level of diploma, social origin or work experience.

There are several ways of entering the CCM profession: holders of the certificate issued by France's civil aviation authority join the company directly with a permanent contract (contrat à durée indéterminée, $\mathrm{CDI}$ ). Other staff have entered with a qualification contract or more recently on a work-study basis (i.e. with a fixed-term contract [contrat à durée determinée, $\mathrm{CDD}]$ ), and have obtained a permanent contract or tenure (generally after only one CDD). They stand out from others who have also entered on fixed-term contracts, so-called complementary on-board staff (COBS), including students hired to help cabin crews on planes during activity peaks, especially in summer. The latter often have several fixed-term contracts (on average 2.8 CDD, and a quarter of them have even had more than five CDD) over one or more years, but very rarely join the company afterwards. Of cabin crew members actually working for the company between 1998 and 2015 at some point, only 16\% (around 4,000) had experienced this type of fixed-term contract; and we removed them from our dataset. The dataset used therefore covers around 21,000 CCM staff whose entire career between 1998 and 2015 was identified. The various variables were taken from separate administrative records which may have different degrees of coverage. Pairing with the dataset that describes network assignments (medium or long haul) slightly reduced the number of individuals: all persons "eliminated" had joined the company before 1998. Matching with another dataset describing working time further reduced the field to around 16,000 individuals. Here again, the majority of "eliminated" persons were relatively old cabin crew members: $91 \%$ had joined the company before 1998, and 38\% in the "resumption" grade; i.e. they came from another company. To avoid such coverage problems and to study the experience a CCM cohort recruited under similar conditions, we selected CCM staff who entered the company between 1998 and 2001 (around 5,000), for whom a maximum career of eighteen years was observed (until 2015). 
(2) The career analysis was also based on the collection of qualitative material, allowing careers to be placed in their social and family context. Thirty in-depth biographical interviews were thus carried out with the cabin crew on permanent contracts with the company; both women and men of various ages and family status (see the Table below). Half of them were hostesses or stewards, the others being cabin managers (CMas) or chief cabin managers (ChMas). These interviews aimed to reconstruct the ways of entry into the profession and their associated representations, by situating them in a longer biographical history. They also sought to bring to light the system of social and family resources on which individuals can rely to pursue "a career", or which weighs on their career (social origin, diploma and previous profession, the possible professional status of a spouse, etc.). Institutional archives (collective agreements for CCMs since 1997, annual social reports, comparative situation reports and three-year agreements relating to professional equality between women and men) as well as the interviews conducted with staff and management representatives finally made it possible to examine differences between the rules governing personnel advancement and the selection practices operated by local managers (in flight), sector managers responsible for examining cases (on the ground) and the joint committees responsible for promotions.

\section{Socio-Demographic Characteristics of the CCM Staff Set Interviewed}

\begin{tabular}{lc}
\hline & Sample $(N=30)$ \\
\hline Gender & 17 \\
Women & 13 \\
Men & \\
\hline Rank & 15 \\
Hostesses/Stewards & 13 \\
Cabin managers & 2 \\
Chief cabin managers & \\
\hline Age & 2 \\
$<35$ years & 4 \\
$35-39$ years & 10 \\
$40-44$ years & 14 \\
$>=45$ years & \\
\hline Number of children & 10 \\
0 & 5 \\
1 & 10 \\
2 & 5 \\
3 and + & \\
\hline Qualification level & 7 \\
High school diploma (baccalauréat) & 18 \\
2 or 3 years of higher education & 5 \\
Master's degree, 5 years of higher education & \\
\hline
\end{tabular}


It may therefore be asked whether women actually exercise this profession in the same way, for the same duration, and with the same chances of promotion as men. Do the latter benefit, as in other highly-feminized tertiary professions, from advantages linked to organizational factors, sometimes called the "glass escalator" (WILLIAMS, 1992; ANGElof, ARborio, 2002; GUICHARD-Claudic et al. 2008; BusCATto, Fusulier, 2013; LOUEY, SCHÜTZ, 2014)? And how have the differences in mobility opportunities between women and men changed in line with changes in the company's human resources policy? Indeed, the cabin crew members studied work in a "semibureaucratic" company context (PocHIC et al., 2011), where careers are organized around advancement based on seniority, which is characteristic of the public services (advancement by rank and scale depending on the date of entry into the company). This is often presented as being less discriminatory against women. ${ }^{2}$ Nevertheless, the privatization of the airline in 2003 was accompanied by the introduction of more individualized workforce management methods, with an expansion of "choice-based" promotion, essentially a form of selection by management after consultation with the company's employee unions (in 1997, only 25\% of annual promotions were based on "choice", whereas since 2003, 50\% of annual promotions have been chosen on the basis of proposals by sector executives and unions, following a formal opinion by the joint committee). These changes in the promotion rules took place at the same time as agreements on professional equality were signed. In this context, it may therefore be asked whether career inequalities between women and men have actually been reduced.

\section{The Unfinished Standardization of Hostesses and Stewards' Careers}

The employment and working conditions of hostesses and stewards were initially separated, but have gradually been merged and harmonized. Since the beginning of the 2000s, a policy of professional equality between women and men has also been implemented, although the economic context has deteriorated sharply at the same time.

\section{From Hostesses and Stewards to Cabin Crew}

Civil and commercial aviation developed in France at the end of World War II, and used to have two types of personnel with different statuses, skills and remuneration on board planes: i) stewards, or former barmen of transatlantic shipping companies who were responsible for preparing meals in line with the tradition of itinerant hotel services; and ii) flight attendants, whose status was created in 1946, and who were

2. "At first glance, the public sector often appears a priori to be more egalitarian and conducive to women's careers, due to the rules governing recruitment, remuneration and professional promotion" (MARRY et al., 2015, p. 4). See also Alber, 2013. However, "glass ceiling" phenomena have also been observed here (MARRY et al., 2017; FREMIGACCI et al., 2016). 
mostly recruited from former Ipsa professions. ${ }^{3}$ The latter came from the middle and upper classes, as borne out at the time by their medical skills and their command of English. They ensured the safety and well-being of passengers, providing first aid on board aircraft.

"During this first period, which lasted until the institutionalization of the cabin crew staff in 1954, transatlantic stewards and Ipsa personnel lived together on planes. Each had its own defined role, and even its territory at certain times: thus at the beginning, stewards had no contact with passengers and only prepared services."

(BARNIER, 1997, p. 22)

In 1954, the professions of hostess and steward merged into a shared profession of cabin crew, replacing the former name of complementary on-board staff (COBS). ${ }^{4}$ The first common training course for hostesses and stewards took place in the same year. The presence of cabin crew on board airplanes henceforth became compulsory and regulated by law: jobs were conditional on obtaining the rescue safety certificate (RSC) issued by France's General Directorate for Civil Aviation (decree of May 24, 1955). At the same time, the salaries and classifications of hostesses and stewards were standardized within the same salary scale.

However, the institutionalization of the CCM profession and the standardization of statutes only led to a partial homogenization of careers between women and men. As a research report from the Ministry of Transport noted in 1982, "the job of hostess was never considered a 'real profession' but rather just as an employment: i.e. a job with limited pay over time, and no career prospects, according to the commercial arguments of the airline companies" (FLORENCE-ALEXANDRE, RIBEILL, 1982). In particular, until 1959, it was compulsory to reclassify hostesses for a ground job after eight years work; while until 1963, women who married were required to resign (BARNIER, 1997). There was also a different age limit for hostesses and stewards. ${ }^{5}$

The terms of hostess and steward refer to historically separate and gender roles. Yet these are still in force in the collective agreements for cabin crew members which govern working conditions and pay, even if the functions of both are now completely identical. By definition, "hostesses and stewards are responsible for ensuring cabin safety and passenger services on board" (the collective agreement of cabin crew members, 1997). They are subject to the same rules of recruitment, pay and promotion that make up the first rank of cabin crew, before those of cabin manager and chief cabin manager (Box 2). Only questions related to maternity and leave help to differentiate hostesses and stewards in company agreements on cabin crew.

3. Ipsa (Infirmières, pilotes et secouristes de l'air) was a professional body created in 1934 within the French Red Cross, of nurses, pilots and air rescuers.

4. COBS refer henceforth only to students on short-term contracts (CDD), i.e. summer jobs during seasonal activity peaks, especially in July and August. They are not responsible for passenger security like CCMs, but only provide customer services, meeting customer expectations as well as possible.

5. Limited to 35 years old until 1955, the age limit was extended to 50 years in 1969 , but only for men. It has been progressively harmonized between men and women, reaching equality today. 
Box 2

\section{Cabin Crew Careers}

The rules for career development vary from one airline to another. However, the hierarchy remains the same, with promotions from the rank of hostess and steward to that of cabin manager and finally chief cabin manager on long haul routes. Cabin managers and chief cabin managers have supervisory staff status (they ensure the distribution of work among employees under their authority on board and under their supervision), while hostesses and stewards are classified as administrative employees in the company nomenclature of professions and socio-professional categories. All hostesses and stewards, cabin managers and chief cabin managers are supervised on the ground by cabin crew managers, who were themselves former cabin crew.

Two types of principles govern the organization of CCMs in the company studied: progress and promotion. Hostesses and stewards are recruited with at least a high school diploma (France's baccalauréat) along with a Cabin Crew Attestation (CCA). They are first placed in an adaptation class for eighteen months, before entering the CCM rank as a 4th class hostess or steward. Each year, on the 1 January, seniority is taken into account for progressing to the next class, according to the rules defined in the CCM convention. On the recommendation of her or his superiors, a CCM may also benefit from a fictitious increase of twelve months in seniority within a class.

After four years of seniority as a CCM in the company, a hostess or steward is eligible to be promoted and become a cabin manager. Promotion to the post of cabin manager or chief cabin manager (i.e. moving to the next rank) occurs in two ways. The cabin crew member may be put forward for selection by her or his superior or may submit an application. A person succeeding in becoming a cabin manager of chief cabin manager is then deployed on flight routes according to the needs of the company. If she or he is not satisfied during the trial period, the employee may return to her or his home flight division. The programming of selection campaigns depends on the company's human resources policy.

The rules of progress and promotion as presented here are taken from the last collective agreement for cabin crew members (having evolved over the course of the company's history).

\section{Changes in the Company's Human Resources Policy: The Gradual Cessation of Recruitments and Measures for Professional Equality}

The company studied here underwent a number of changes in its human resources (HR) policy over the period, linked to general changes in the economics of the airline sector, and to legislative changes obliging large companies to negotiate on professional equality measures between women and men. The period was thus characterized by a context of significant hires, particularly at the end of the 1990s and the beginning of the 2000s, before the sector went into crisis in 2009. This is borne out by our analysis of personnel flows and the reasons given for entering and leaving the CCM profession between 1998 and 2015. From 1998 to 2001, entries into permanent or tenured CCM 
posts were on average five times greater than the departures. The number of hostesses and stewards was growing strongly. Then, from 2002 to 2008, the entries decreased but remained higher than the exits, even though the latter increased. The stock of CCMs continued to grow, but more slowly. In 2009, the entries and exits of incumbents were more or less balanced, yet since then, exits have always been more numerous than entries, while there was even a total stop to recruiting tenured staff from 2012 to 2015. The rare entries during this period only concerned seasonal staff (COBS). The reasons for leaving the company were also changing, with a large share of exits from 2002 to 2012 being due to retirement (retirements at the time represented between half and three quarters of leavers, depending on the dates; apart from leavers with fixed-term contracts), and also the emergence of voluntary departure plans (VDPs) at the end of the period (accounting for two thirds of leavers between 2013 and 2015). These changes reflected developments in the French air transport sector. While flourishing for a long time, established companies experienced a marked slowdown from the mid2000s with the arrival of low-cost companies in the medium-haul sector (Europe) and Gulf airlines in the long-haul sector. The aviation sector as a whole, and particularly the company studied, have therefore experienced a major change in their operating environment, with important effects on the careers of in-flight staff, as we shall see.

The period was also characterized by the development of a policy on gender equality. In fact, from the 2000s onwards in the airline studied here (as in most large French companies) taking account of professional equality between women and men became a legal obligation. This has been implemented in company agreements or in ad hoc documents drawn up by personnel management services. Given the legal obligation for firms with 50 or more employees to publish a comparative situation report (CSR), the airline stepped up the drafting of texts (charters of good practice, agreements and action plans) relating to workplace equality, noting that "the publication of the annual report on the comparative situation of women and men (CSR) is part of a broader policy framework aimed at promoting professional equality" (CRS 2014 CCM, p. 3). Specifically, the implementation of this policy has involved: the signing of three triennial agreements between 2002 and 2014; the establishment of an action plan for 2014-2015; and the inclusion of this issue in salary agreements since 2008. Two statistical indicators have been monitored mainly: i) gender pay gaps at equal rank (measured by the gross annual tax income of CCMs, cabin managers, chief cabin managers and executives); and ii) the number of women and men promoted annually to various management positions. In addition to these legal indicators, set by decree nationally, a series of indicators has been adopted following proposals by the company's professional equality commission. ${ }^{6}$

6. These indicators are: the share of employees on alternating time (detailed by type); the share of hires on permanent contracts (CDI); the share of CDI recruits tenured after fixed-term contracts (CDD); the breakdown of reasons for leaving; the taking of sabbatical leave exceeding six months; the number of training hours followed annually; and access to local services (child-care). Most of these additional indicators are not broken down by gender, with the exception of alternating time, but by staff category. 
On the whole, the CSRs emphasize the "small pay gap" between hostesses and stewards, in the order of " $€ 162$ gross per month in 2014", although these gaps widen with promotion into management positions. They are then explained by the differences in effective flight time, with women resorting more frequently to alternating time, ${ }^{7}$ and so automatically losing a large share of their salaries, which are linked to flight bonuses and daily allowances received during flight rotations. In addition, the reports highlight the equal number of women and men promoted annually to different ranks as a sign of progress in standards and practices of professional equality within the company. However, the finalization of the 2011-2013 triennial agreement stumbled on the integration of relative promotion indicators requested by the main flight attendants' union: i.e. indicators which report the number of women and men promoted each year relative to the number of people of each gender eligible for promotion from the lower cohort.

These relative indicators, although of central importance, provide a truncated view of careers. To analyze the differences in careers between women and men, it is necessary to analyze their entire career paths: entries, progressions and exits. Have changes in the company's HR policies thus led to a convergence of women and men's situations at different stages of their careers?

\section{The Apparent Convergence of Women and Men's Careers among Cabin Crew}

Initial indicators, based on cross-sectional statistics from personnel records, suggest there has been a convergence of careers between women and men. This was confirmed by the interviews.

\section{A Fall in the Proportion of Women, a Higher Entry Age into Careers and a Convergence in the Reasons for Leaving}

During the period studied, the conditions of entry into careers as hostesses and stewards have tended to converge, according to personnel records. Thus, women represented $67 \%$ of the all cabin crew over the period 1998-2015. But their share of incoming flows was greater than or equal to 67\% between 1998 and 2000, and then decreased to around 58-60\% in 2007-2008 - a historically low level (Figure 1). At the same time, the median ages of career starts increased and converged, with a slightly more marked increase for women (up from 24 years in 1998 to 27-28 years in 2005-2008,

7. This is a form of part-time work specific to the airline sector. Alternate working-time involves a succession of periods of activity and inactivity without pay, with quotas equal to 50\%,66\%, 75\%,80\% and 92\% of full-time work, per calendar year. For example, a CCM on a $75 \%$ quota works for three months, followed by one month of inactivity without pay. 
FIGURE 1 - CCM Entry Flows of Women and Men, 1998-2011

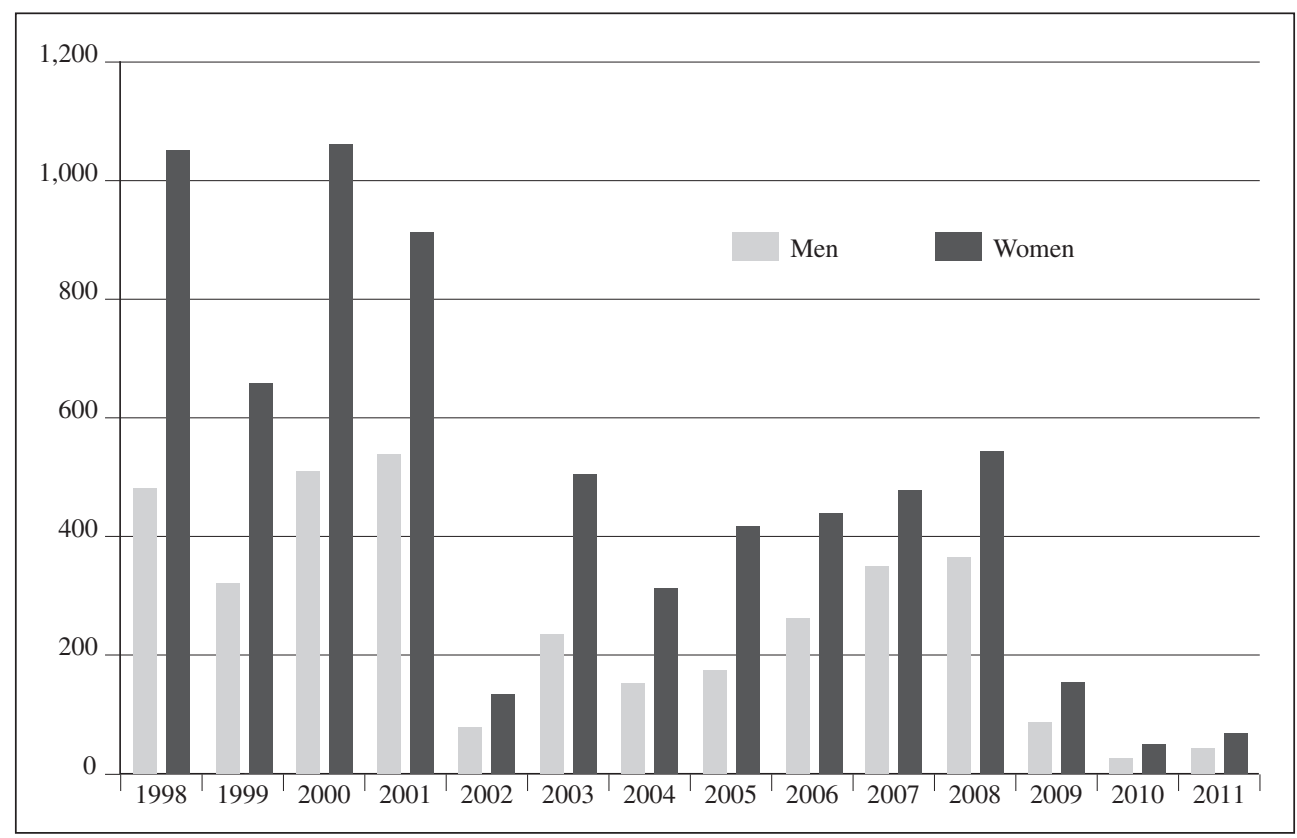

Interpretation: In 2001, about 500 men and 900 women obtained permanent contracts as CCMs or fixed-term contracts which led to tenure.

Field: First entries as permanent CCMs or with fixed-term contracts that led to tenure, 1998 to 2011.

Source: Company personnel records (authors' calculations).

and even 29 years at the end of period) than for men (up from 26 years to 28-29 years, and then to 29 years at the end of the period, the same as for women). ${ }^{8}$ Finally, the family composition at career starts differed little between women and men, a very large majority having few or no children when taking their first position. ${ }^{9}$ This was the case for example of $98 \%$ of the men and $99 \%$ of the women who joined the company as CCMs in 1999.

The models of entry into CCM careers have historically been differentiated between women and men, and have therefore evolved over time and seem to be converging, albeit in a context of economic crisis which has led more varied profiles of men entering the profession. Indeed, the increase in the median age of career entry suggests a change in recruitment profiles over time, towards higher educational levels ${ }^{10}$

8. However, the criteria for recruiting cabin crew remained unchanged during the entire period: candidates have to be 18 years old or more, hold a high school diploma, have French or EU nationality, pass medical tests successfully, know how to swim, speak fluent English, and have a clean criminal record (source: company agreements).

9. The personnel records include an employee's child or the child of a partner, whether it is a child of the partnership or not.

10. The diploma variable is not included in the database, as diplomas are not a determinant for entry into the CCM profession, in which all new entrants start as hostesses and stewards in the same class. It is therefore not possible to establish a statistical link between the median age of recruitment and the diploma level of recruits. However, the interviews conducted strongly suggest that new recruits are more qualified than former generations. 
or recruitment of candidates with previous work experience. While only a high school diploma is legally required for recruitment as a CCM, interviews with stewards reveal the prevalence of higher education diplomas (master's degrees in law, in social sciences, second tier business schools, two-year vocational tourism diplomas, etc.). In addition, interviews with HR managers show that as recruitments have slowed down, the company has sought to hire cabin crew with some work experience and/or who have completed two-year vocational higher education (especially France's two-year BTS tourisme). As entering the job market has become more difficult, this profession has been able to attract graduates due to its employment and pay conditions. These often dominate in job choices put forward by the men interviewed, ahead even of the attractiveness of aviation or a taste for travel. This is what Stéphane said:

"I have always wanted to work for X. The company is a reference in France in terms of working conditions and pay, as well as all the extras, on CVs, etc. Socially speaking, it's still a great company."

(Stéphane, 41, cabin manager, Master's degree in law, no children)

In comparison, the women interviewed presented their choice of being a hostess, if not as a vocation (which was relatively rare), then at least as being self-evident, a kind of "logical continuation" of studies focused on tourism and/or service sector professions (with a Bachelor's degree in applied foreign languages, a two-year vocational diploma (BTS tourisme), or a BTS as a trilingual secretary, or even a Bachelor's degree in psychology), with a focus on customer relations (passenger care), smart presentation (wearing a uniform, training in body care, etc.). The possibility of travelling was also sometimes presented as being emancipatory vis-à-vis parental authority and the family norms that weigh on women (pressure to be in a couple, to marry and have children). Entry into the profession often took place in successive stages, first as a seasonal worker or on short-term contracts in second-tier companies (charter carriers, etc.). This was the case of Noémie, the daughter of a teacher and a postman, who started working on flights while studying English at university:

"At the time, I was leaving boarding school, I was not very serious. I partied a lot. In tutorials and everything, it was... I was there. I was present, but I was too relaxed about work. And when I got to university, I found out how you actually learn to fly! I regret it, because I could have completed my bachelor's degree. But well, I have a job that suits me completely, meeting people, talking with them..."

(Noémie, 38, cabin manager, high school diploma)

In this case, the interviews carried out with the hostesses often reveal a limited projection of their careers over time: work as a flight attendant is presented as an occupation which gradually becomes a profession:

"I travelled very little as a child, and so I dreamt about it. It is true that in the beginning, you say to yourself that you are going to do this for a while, and then in 
fact the advantages, the way of life, the standard of living also mean that, well, you rarely stay one or two years."

(Sylvie, 43, cabin manager, BTS in technical marketing and a two-year diploma in law)

"Me, I always lived it as a job of an epoch [sic], for a moment. When I joined X, I knew I wouldn't spend my entire career here, it was a job for my twenties and thirties, I didn't want to go on until retirement."

(Maïté, 45, hostess, Master's degree in English literature)

These representations of careers as cabin crew were reconstructed ex post in biographic interviews. They thus reveal a certain difference between men and women. Whereas the former immediately consider the job of CCM over the long term, the latter do not seem to make such long-term projections, or else anticipate an adjustment in mid-career when having a first child, which on average occurs at a later age for hostesses than in the rest of the French population. The words of these hostesses contrast with those of David, son of an aviation mechanic:

"So why did I choose to join X? Because with X, you're on track until retirement!"

(David, 48, steward, BTS land use planning)

These differentiated time projections are also visible in the distribution of reasons for leaving and the distribution of exit ages between men and women (Figure A1 in the Appendix): for the period 1998-2015, men on average left the company three years later than women (at 50 compared to 47). More often, departure was due to retirement or as part of a voluntary redundancy plan (aimed at employees at the end of their career). On the other hand, women are over-represented among job resignations, which are few (voluntary quits accounted for only $18 \%$ of the exit reasons for hostesses who left between 1998 and 2015). But these occurred fairly early in their careers (at 34 on average for women). Hostesses also retire on average at a younger age than stewards. Reclassifications on the ground are very rare (less than one percent of the reasons for leaving); they concern situations where the cabin staff lose their license to fly. These differences in the reasons for leaving between women and men were significant at the start of the period studied, but subsequently declined: in 1998, 73\% of the hostesses left the company by resignation, compared to $57 \%$ for stewards; in 2008, the first reason for leaving for both genders was retirement $(68 \%$ for hostesses and $76 \%$ for stewards) even though women were still over-represented among resignations (16\% of reasons for leaving, compared to $10 \%$ for men). In 2015, this over-representation of women in resignations was no longer observed and resignation had become almost non-existent ( $1 \%$ of exits of both men and women). Instead, in 2015, 90\% of exits for both sexes occurred as part of a voluntary redundancy plan. 


\section{An Increase in the Share of Women in Management Positions and of Part-Time Work for Both Sexes}

The ways of entering and exiting the careers of hostesses and stewards therefore appear to have converged in the period from 1998 to 2015. So, what about their working conditions and access to management positions?

Table 1 sets out the distribution of men/women across different career ranks, from the lowest (hostesses/stewards) to the highest (ground managers), by looking at the stock of cabin crew members at different dates. While women are in the majority at the lower levels, their share decreases moving up the hierarchy. Their share in higher ranks has nevertheless increased recently, to stabilize around at $64 \%$ in the positions of cabin manager (CMa) and $60 \%$ for chief cabin manager (ChMa). While women still appear to be slightly under-represented in management positions, the glass ceiling seems to have weakened from the beginning of the 2000s for access to the CMa rank and more recently to that of ChMa.

TABLE 1 - Distribution of the Stock of CCMs by Gender and Function

\begin{tabular}{lcccccccc}
\hline & \multicolumn{2}{c}{$\mathbf{1 9 9 8}$} & \multicolumn{2}{c}{$\mathbf{2 0 0 2}$} & \multicolumn{2}{c}{$\mathbf{2 0 0 8}$} & \multicolumn{2}{c}{ 2015 \% } \\
\cline { 2 - 9 } & Men & Women & Men & Women & Men & Women & Men & Women \\
\hline Hostess/steward & 29 & 71 & 31 & 69 & 32 & 68 & 32 & 68 \\
CMa & 41 & 59 & 38 & 62 & 36 & 64 & 36 & 64 \\
ChMa & 54 & 46 & 54 & 46 & 48 & 52 & 40 & 60 \\
Manager & 54 & 46 & 53 & 47 & 48 & 52 & 48 & 52 \\
All ranks & 34 & 67 & 34 & 66 & 34 & 66 & 33 & 67 \\
\hline
\end{tabular}

Interpretation: In 1998, 71\% of CCMs (hostesses and stewards) were women, while they accounted for 59\% of cabin managers (CMa) and $46 \%$ of chief cabin managers (ChMas) and managers.

Field: CCM stocks including persons on fixed-term contracts who get tenure or who are in "resumption" in 1998, 2002, 2008 and 2015.

Source: Company personnel records (authors' calculations).

Regarding working conditions, the distribution of men and women between medium and long-haul routes shows a slight over-representation of women for medium-haul: the gap between men and women is statistically significant, but it is small and is not increasing (Table 2). Women are clearly over-represented in part-time work, especially in the lowest hourly quotas $(50 \%, 66 \%$ and $75 \%)$. Part-time work increased over the period for both genders, but more clearly for women, especially for "long" quotas $(83 \%, 92 \%)$. This is linked to the incentives given to employees by the company, in particular through the "alternate time" measure to manage over-staffing related to the decline in short and medium-haul activity.

In short, the cross-sectional data suggest a certain convergence in the careers of women and men, and in particular a weakening of the glass ceiling for the generations recruited before the 2000s, and probably even before the 1990s. Women were the overwhelming majority of hires at that time. Some of them automatically acceded to 
TABLE 2 - Distribution of CCM Stock by Work Position Characteristics

\begin{tabular}{|c|c|c|c|c|c|c|c|c|c|c|c|c|}
\hline & \multicolumn{3}{|c|}{1998} & \multicolumn{3}{|c|}{2002} & \multicolumn{3}{|c|}{2008} & \multicolumn{3}{|c|}{2015} \\
\hline & Total & Men & Women & Total & Men & Women & Total & Men & Women & Total & Men & Women \\
\hline \multicolumn{13}{|l|}{ Network } \\
\hline $\begin{array}{l}\text { Medium- } \\
\text { haul }\end{array}$ & 34 & 29 & 36 & 31 & 29 & 32 & 25 & 23 & 26 & 23 & 19 & 25 \\
\hline $\begin{array}{l}\text { Long- } \\
\text { haul }\end{array}$ & 66 & 71 & 64 & 69 & 71 & 68 & 75 & 77 & 74 & 77 & 81 & 75 \\
\hline \multicolumn{13}{|c|}{ Hourly rate } \\
\hline $50 \%$ & 5 & 1 & 7 & 5 & 1 & 7 & 6 & 2 & 8 & 6 & 2 & 7 \\
\hline $66 \%$ & 5 & 1 & 7 & 6 & 1 & 8 & 5 & 1 & 8 & 5 & 1 & 7 \\
\hline $75 \%$ & 6 & 3 & 8 & 6 & 2 & 8 & 8 & 3 & 11 & 9 & 3 & 12 \\
\hline $83 \%$ & 2 & 2 & 3 & 4 & 3 & 4 & 7 & 4 & 8 & 10 & 5 & 12 \\
\hline $92 \%$ & 5 & 5 & 5 & 5 & 4 & 5 & 7 & 6 & 8 & 9 & 8 & 10 \\
\hline $100 \%$ & 76 & 88 & 71 & 75 & 88 & 68 & 66 & 84 & 57 & 61 & 81 & 51 \\
\hline
\end{tabular}

Interpretation: In 1998, 36\% of women CCMs were on medium-haul flights compared to $29 \%$ of men, and to $34 \%$ for all CCM staff. $71 \%$ of women worked full time, compared to $88 \%$ of men.

Field: Stocks of permanent or tenured CCMs, 1998, 2002, 2008 and 2015.

Source: Company personnel records (authors' calculations).

managerial positions, given the rules for promotion by seniority. However, differences in the chances of promotion seem to persist between men and women, as the latter remained under-represented in managerial positions, even in 2015 . We then tried to explain this persistence, by comparing the cohorts of women and men who joined the company at the same time, and by observing at what point career inequalities were established. In addition, the convergence of recruitment conditions between women and men more recently, within a context of promoting professional equality, raises questions about changes in the chances of promotion, according to gender for CCMs recruited later (in the late 1990s to early 2000s).

\section{Career Models Remain Gendered with Fewer Promotion Chances for Women}

The comparative analysis of the careers of a cohort of hostesses and stewards recruited at the turn of the 2000s shows that the chances of promotion for men remain higher than those for women, especially for men without children. The differences in promotion chances according to gender are linked not only to a different relationship to fertility between hostesses and stewards, but they are rooted in gendered career models, with an over-representation of women working in part-time careers for family reasons. 


\section{A Glass Escalator for Childless Men}

To compare and analyze the development of careers within a cohort of recentlyrecruited CCMs, we selected entries between 1998 and 2001, for whom we could therefore observe up to eighteen years of their career (through to 2015). This cohort entered the company at a time of strong economic and workforce growth. Two-thirds (66\%) of this cohort's entrants were women and began their careers with fixed-term contracts (Table 3). A similar yet low percentage (around 7\%) of women and men in the cohort had left the company before 2015 . While $98 \%$ of the stewards and $99 \%$ of the hostesses in the cohort did not have children on entering the company, the gap widened during their careers: $25 \%$ of these women still had no children in their last year of observation (2015), compared to $46 \%$ of men. Above all, hostesses' chances of promotion were lower: $16.1 \%$ of men in the 1998-2001 cohort were promoted during the observation period, compared to $8.7 \%$ of women. So, it may be asked at what point in their careers did these gaps arise and what were the associated factors? Can we establish a link with the differentiated relationship hostesses and stewards have with fertility?

\section{TABLE 3 - Description of the CCM Cohort Entering the Company between 1998 and 2001}

\begin{tabular}{lcccc}
\cline { 2 - 4 } & $\mathbf{1 9 9 8}$ & $\mathbf{1 9 9 9}$ & $\mathbf{2 0 0 0}$ & $\mathbf{2 0 0 1}$ \\
\hline Breakdown by year of entry & 28 & 18 & 28 & 26 \\
\% Men & 32 & 33 & 33 & 37 \\
\% Women & 68 & 67 & 67 & 63 \\
\hline Median age at entry & & & & \\
Men & 26 yrs & 26 yrs & 26 yrs & 27 yrs \\
Women & 24 yrs & 25 yrs & 25 yrs & 26 yrs \\
\hline \% Of entries on fixed-term contracts & & & & \\
Men & 83 & 89 & 59 & 48 \\
Women & 89 & 90 & 50 & 39 \\
\hline
\end{tabular}

\begin{tabular}{lcc}
\cline { 2 - 3 } & Men & Women \\
\hline \% with no children at entry & 98.0 & 99.0 \\
\% with no children at exit & 46.0 & 25.0 \\
\% promoted & 16.1 & 8.7 \\
\% of exits before 2015 & 6.5 & 7.0 \\
\hline
\end{tabular}

Interpretation: Between 1998 and 2001, about 5,000 cabin crew joined the company. The men's share of admissions tended to increase slightly, from $32 \%$ in 1998 to $37 \%$ in 2001 . The median age at entry of both men and women also increased. Only $7 \%$ on average $(6.5 \%$ of men and $7 \%$ of women) quit their jobs as CCMs before 2015, the last year of observation.

Field: Cohort of new entrants as CCMs into the company (on fixed-term contracts or fixed-term contracts leading to tenure) between 1998 and 2001.

Source: Company personnel records (authors' calculations).

A simple model for duration before the first promotion (the actuarial method) shows that during the first seven years after recruitment, members of the cohort (both women and men) did not experience any promotion (Figure A2 in the Appendix). The rules governing promotions within the company do indeed impose minimum lengths of 
service (generally four years), which have tended to lengthen in the poorer economic context. Then, the curves representing the time lapse before the first promotion by gender diverged gradually, but "promotion events" remained relatively rare for the whole cohort, while the chances of promotion were not constant during the whole period of observation: promotions were numerous from 2006 to 2008, then slowed down markedly until 2014.

The same model for the "final" number of children (recorded at the last observed reading) seems to indicate that $\mathrm{CCMs}$ with children are less likely to be promoted than those without. Moreover, differences in the speed of promotion according to the number of children seem greater among men than among women. In addition, the advantage of being childless has for the chances of promotion seems to be higher for men than women - the slope of the male curve is indeed steeper than that of the female curve. We have also seen that a greater proportion of stewards remained childless compared to hostesses. Furthermore, the "accelerator" effect of being a man on the chances of promotion may be due, at least in part, to different fertility rates between women and men among CCMs, and we must try to isolate this effect from other explanatory factors for the higher chances of promotion for men, by using a regression model.

Moreover, these initial models of duration consider the fact that certain individuals are not observed throughout the maximum observation period because they left the company early: some data are therefore truncated or censored. However, the models assume that this interruption process does not provide information about what we are trying to measure. Yet, we can assume that some cabin crew members leave the company because they are not promoted, especially persons whose departure is recorded for certain administrative reasons (such as resignations), and we have seen that the distribution of these reasons differs between women and men. To take into account these two possible outcomes - promotion and exit from the CCM profession and to analyze the effect of the different variables, ceteris paribus, we implement a discrete-time multinomial logistic regression model (AlLISON, 1982). ${ }^{11}$ It allows the probability of identifying an event to be modelled (here promotion or exit), knowing that it had not been identified before. Certain explanatory variables introduced are constant over time (gender, age at entry, etc.), others are not (full-time work duration, long-haul duration and number of children). The results (Table 4) show that women have, other things being equal and in particular with regard to the number of children controlled for, lower chances of promotion than men, but do not show a significantly higher probability of leaving. Individuals who became CCMs at a younger age have more chances of promotion, yet this is even more so for older-entry personnel. We may assume that the latter are more qualified or more experienced professionally before joining the company. Individuals who entered on fixed-term contracts are promoted less. Having children, regardless of the number, reduces the chances of promotion compared to persons who are childless. Moreover, in separate models for women and

11. This type of model is particularly well-adapted to time discrete data, as in the case here (one observation per year), and it allows concurrent events to be modeled by using multinomial regressions. 
TABLE 4 - Multinomial Time-Discrete Logistic Regression (odd ratios)

\begin{tabular}{|c|c|c|}
\hline $\begin{array}{l}\text { Risk of... (ref = neither observed promotion } \\
\text { nor exit between CCM entry and 2015) }\end{array}$ & Promotion & Exit before 2015 \\
\hline $\mathrm{T}$ & $1.21^{* * *}$ & NS \\
\hline \multicolumn{3}{|l|}{ Gender } \\
\hline Woman & $0.67^{* * *}$ & NS \\
\hline Man & ref. & ref. \\
\hline \multicolumn{3}{|l|}{ Entry age as CCM } \\
\hline$<23$ years & $1.31^{* *}$ & NS \\
\hline $23-25$ years & ref. & ref. \\
\hline $26-27$ years & NS & NS \\
\hline 28 years or more & $2.36^{* * *}$ & NS \\
\hline \multicolumn{3}{|l|}{ Number of children } \\
\hline None & ref. & ref. \\
\hline 1 child & $0.67^{* * *}$ & $0.58^{* * *}$ \\
\hline 2 children & $0.69^{* * *}$ & $0.60^{* * *}$ \\
\hline 3 children or more & $0.64^{* *}$ & NS \\
\hline Entry with fixed-term contract (CDD) & $0.79^{* * *}$ & $0.78^{* *}$ \\
\hline Duration of work on long-haul routes & $0.97^{* *}$ & $0.94^{* * *}$ \\
\hline Duration of full-time work & $1.14^{* * *}$ & $0.95^{* * *}$ \\
\hline
\end{tabular}

men (not shown here), this negative effect of children on the chances of promotion increases with the number of children for women, while it is only significant for one child for men. Finally, the duration of full-time work increases the chances of promotion, while the duration of long-haul work decreases them.

In short, the differences in promotion opportunities between women and men seem to be rooted in different career models. At this stage, two gendered career models seem to stand out: i) part-time work for women hostesses who have children; and ii) full-time work and promotion for men who have less children. However, additional analyzes are necessary to understand better the diversity of careers and the way in which they are structured.

\section{Hostesses' Part-Time Careers for Family Reasons}

To account for the diversity of cabin crew careers and their gendered nature, in particular concerning links between career type and chances of promotion, we created a typology of careers for the cohort of cabin crew members recruited between 1998 and 2001, and still with the company in 2015 . We therefore exclude here, by definition, hostesses and stewards who left the company before 2015: i.e. CCMs with short careers whom we have seen were relatively few in number, as well as being women and men 
in equal proportion. The aim is to highlight different career models among persons with comparable seniority in the company. To create this typology, we summarized career paths using synthetic quantitative indicators (duration, number of transitions) for various career dimensions: ranks, working time and assignment to different types of networks (long or medium-haul; see Table A3 in the Appendix). ${ }^{12}$ These indicators are the active variables of an ascending hierarchical classification. We distinguished five career classes that we described by analyzing the over- and under-representation of each active variable in the different classes. By crossing the classes obtained with the socio-demographic variables (additional variables), in particular the number of children or gender, it is also possible to characterize better each of the classes (Table 5). These are also illustrated by typical cases from the interviews.

\section{TABLEAU 5 - Typology of Careers}

\begin{tabular}{|c|c|c|}
\hline & $\begin{array}{c}\text { Class weight } \\
\text { in cohort }\end{array}$ & Description of classes \\
\hline Class 1 & $56 \%$ & $\begin{array}{l}\text { Full time, long haul, no promotion. } \\
\text { Average seniority (CCMs entered in 2000/2001, often on a CDD). } \\
\text { Few children for women ( } 1.42 \text { on average) and for men (1.11). }\end{array}$ \\
\hline Class 2 & $10 \%$ & $\begin{array}{l}\text { Full-time, medium-haul, no promotion. } \\
\text { Lots of network changes. } \\
\text { Average seniority (CCMs joined in } 2000 \text { and 2001, not on fixed-term } \\
\text { contracts). } \\
\text { Few children for women (1.19 on average) and for men (1.12) }\end{array}$ \\
\hline Class 3 & $18 \%$ & $\begin{array}{l}\text { Part-time (alternating, parenting), long-haul, no promotion. } \\
\text { Hourly quotas }(66 \%, 75 \%, 83 \%) \text { strongly over-represented. } \\
\text { Very few network changes. } \\
\text { CCMs who joined in } 1998 \text { or } 1999 \text {, often on fixed-term contracts. More } \\
\text { children for women }(1.72 \text { on average) but not for men (1.05). }\end{array}$ \\
\hline Class 4 & $10 \%$ & $\begin{array}{l}\text { Full-time, promotions, medium-haul slightly over-represented. Cabin } \\
\text { managers, chief cabin managers, executives. } \\
\text { CCMs in } 1998 \text { and at an older age than average. } \\
\text { Low number of children on average for both men (0.85) and women (1.11). }\end{array}$ \\
\hline Class 5 & $7 \%$ & $\begin{array}{l}\text { Part-time (alternating, parental, other part-time), medium-haul. Some } \\
\text { promotions to cabin manager, but rare ( } 9 \% \text { of individuals in the class). Many } \\
\text { changes in hourly rates. Particularly over-represented quotas: } 50 \%, 92 \% \text {. } \\
\text { CCMs joined in } 2001 \text {, not on fixed-term contracts. } \\
\text { More children for women ( } 1.72 \text { on average) but not for men }(0.74) \text {. }\end{array}$ \\
\hline
\end{tabular}

Distribution of men and women in the classes

\begin{tabular}{lcccccc}
\hline & Class 1 & Class 2 & Class 3 & Class 4 & Class 5 & Combined \\
\hline Men & 40 & 33 & 15 & 51 & 12 & 34 \\
Women & 60 & 67 & 85 & 49 & 88 & 66 \\
\hline
\end{tabular}

Field: CCMs recruited as CCMs between 1998 to 2001 (fixed-term and permanent contracts) and still CCMs with the company in 2015. Source: Company personnel records (authors' calculations).

12. The data were centered and reduced and Ward's criterion was used for aggregation. Indicators were standardized to take into account different careers depending on the year of entry as a CCM (1998, 1999, 2000 and 2001). 
The first class makes up the majority of the cohort (56\%). It includes full-time hostesses and stewards, on long-haul routes, who were not promoted: $98 \%$ were still hostesses or stewards during their last year of observation. On average, $87 \%$ of their careers were spent long-haul, and $89 \%$ full-time (96\% of that of men and $84 \%$ of that of women). Men are over-represented in this class: they made up $40 \%$ of the class compared to $34 \%$ of the overall cohort (Table 5). The average number of children is 1.11 for men ( $42 \%$ have no children) and 1.42 for women. Persons in the cohort with the least seniority (who entered in 2000 or 2001) and who started on fixed-term contracts were over-represented. This class not only includes individuals who show a certain distance to work, and who have detached themselves from career ambitions. The size of the class is also boosted by the slowdown of the company's internal labor market as of 2009. The career path of Jules, a 45-year-old steward living with a partner but without children, appears emblematic of this category. He joined the company in 1998 after obtaining an engineering diploma in aeronautical maintenance: he worked for a year and a half on medium-haul routes before moving to long-haul:

"I don't envisage this job on medium-haul. For me, that would not be interesting at all. The advantage for me is to travel, to go to places, to have a little time in stopovers..."

At the same time, he quickly became a union delegate, which enabled him to cope better with the fatigue associated with long-haul flights:

"It was too tiring. I didn't see myself doing it all my life. I would have liked to have worked alternating time like some do, but I was not earning my living enough. So I stayed there. I found this solution with the union."

After almost fifteen years, Jules presents himself as a "simple steward". He analyzes, with a certain bitterness, the interrupted dynamics of his career:

"Today, I am a steward. I had six selections to be a cabin manager, and each time, I was turned down. And I still haven't become one through seniority... With my union mandate, I have been able to negotiate a lot. All that, well they leave me alone. But now it is costing me. It's true - well, I've never really had a career."

The second class is made up of careers that were also full-time (91\% of the duration of careers in this class on average), this time on medium-haul routes (more than three quarters of a career on average). This class accounts for $10 \%$ of the cohort, $67 \%$ of whom are women. The latter are therefore very slightly over-represented. Almost all of the CCMs in this class had not had a promotion ( $99 \%$ were still hostesses or stewards in 2015). Full-time cabin crew can choose to work in the medium-haul sector when they have children, to have as few nights away as possible in their flight schedule (this is also one of the two classes that has the most network changes: 3.4 on average for women and 3 for men). This was a choice made by Marie-Pierre, 40, cabin manager and mother of two children, who had been doing this job for fifteen years, after having obtained a Bachelor's degree in applied foreign languages. She had 
flown medium-haul for a long time, and for more than three years had been working on domestic day flights:

"It was easier for me to take care of my daughters. I had asked to do mainly morning flights. It's quite intense, because we do four flights a day. It was quite... quite tiring. For the others, for my family, it was very good [laughs]."

She recently switched to $80 \%$ alternating time, a temporary measure of subsidized part-time work linked to over-staffing. This gave her two months "off", yet she planned to resume full-time work thereafter for financial reasons. More generally, this class includes CCMs who are still quite young in their careers (who often entered in 2001 or 2000), and who often do not (yet) have many children (1.12 on average for men and 1.19 for women), and so managed to reconcile their private or family lives with full-time work on medium-haul routes. But we can see that this position seems more tenable for men with children than for women in the same situation. In fact, men with one or two children are over-represented in this class compared to women with no or one child.

The third type of career (Class 4) covers almost all staff who were promoted, for both women and men: $93 \%$ were cabin managers in 2015, 5\% were managers and the rest were chief cabin managers. Men are very largely over-represented, making up more than half of the class (51\%). These CCMs had worked full-time for almost their entire careers (86\%) and had spent a large part working on long-haul routes $(71 \%$ on average). However, all of them had experienced more network changes than the CCM average, and the time spent on medium-haul routes was slightly over-represented. This is the class where the average number of networks that CCMs had worked on is indeed the highest (4). In both cases, women and men in this class had few children, which is an indication of the link between family availability and the fact of "pursuing a career": this is indeed the class where the average number of children was lowest for women (1.11) and the second lowest for men (0.85). The oldest along with CCMs who joined the company in 1998 were also over-represented in this class, which testifies to the role of seniority (or even diploma and previous job experience) in promotions. François, 55, is characteristic of this type of career. He had been a cabin manager for thirteen years on the long-haul network, had always worked full-time since joining the company in 1998, after training as an industrial designer. He had no children, was divorced and dedicated a large part of his free time to aeronautics (he was training as a private pilot) and to horse racing. He would have liked to become an airline pilot but had failed the selection several times. In an interview, he stated he was satisfied with his work, which in his eyes combines good pay and free time:

"I often ask for flights to $\mathrm{X}$ because I ride a horse, it costs me a fortune. And so, to pay for my hours of riding, I go to X. I take a good book, the hotel is nice, there is a swimming pool, there is sport, I take walks outside, in a Zen park, and when I get home I have $€ 250$ to pay for groceries."

He also enjoys cabin service, especially business class in which he often works. 
The last two career types correspond to two classes in which the cabin crew frequently work part-time. Part-time work has been encouraged by the company in recent years. These two classes concern women more often than men: women represent $85 \%$ of the workforce in Class 3, and $88 \%$ of Class 5. Class 3 is a part-time class (alternating or parental time) for long-haul routes, and accounts for $18 \%$ of the cohort's workforce. In this class, the average length of time working on long-haul routes was the highest ( $88 \%$ of the staff careers). On average, only $35 \%$ of CCMs' careers in this class had been full-time. Medium to long part-time quotas (66\%, 75\% and $83 \%)$ were particularly over-represented. The crew members concerned had a higher number of children than the average: 1.05 children for men and especially 1.72 for women. Men with one child were over-represented, as were women with two or three children or more. The vast majority ( $99 \%$ of women and $98 \%$ of men) in this class had not been promoted. However, the CCMs who joined the company in 1998 or 1999 and who are relatively old were over-represented. The career path of Marie-Christine, 43, hostess, appears typical of this category. Joining X in 1998 on long haul routes, after obtaining a Bachelor's degree in psychology, she had three children, which had led her to stop flying for almost ten years. Returning from parental leave, she resumed her part-time long-haul activity. In her eyes, this was "why [her] career had not taken the turn that [she would] have liked". Marie-Christine finally left the company in 2015, as part of a voluntary redundancy plan, due to the lack of prospects for professional development, linked to the airline's poor economic situation and her irregular career.

The last typical career also concerns a class of part-time work (be it alternating, parental or other part-time work). But it is more atypical, covering $7 \%$ of the cohort's workforce, operating mainly on medium-haul routes. Only an average 37\% of CCM careers in this class were with full-time work (40\% for men and $36 \%$ for women), and three-quarters concerned medium-haul routes. The very short part-time quotas (50\%) and very long quotas (92\%) are over-represented in this class, the former mainly involving women and the latter men. This shows up two different uses of part-time work according to gender. For women in this class, part-time seems to be the same as classic part-time work for family reasons: also, women have the highest average number of children (1.72), and women with two, three or more children are overrepresented. Moreover, their rate of part-time work (frequently 50\%) is high. Julie, 46 , was a hostess who graduated from a second tier business school. She is divorced and the mother of two teenagers. She has worked part-time on medium-haul since the birth of her daughter. She worked $75 \%$ for twelve years, to the detriment of promotion:

"I always worked $100 \%$ until Juliette was born in 2004. And I almost went to working $66 \%$. And, then as I got divorced, I said: 'No, no, no, this isn't going to be possible. I'll try to stick to $75 \%$ and that's it.' I stayed at $75 \%$. [...] I have been able to manage the children since I was divorced, having joint custody. But as I'm not on $100 \%$, I never made it to being a cabin manager, because, well, I have the hostess seniority which allows me to have a little more... For the rest, it's a choice of life. For me, being promoted was not an end in itself. My personal life was more important." 
The men who belong to this class have a relatively atypical profile: they work part time, on short or long hourly quotas $(50 \%, 75 \%$ or even $92 \%)$ but obviously not for family reasons since childless CCMs are over-represented in this class: the average number of children for men in this class is 0.74 , the lowest of all classes. In addition, they work alternate time or part time. For staff representatives and management alike, this provides a "month for surfing" that men devote to their leisure activities. The CCMs who entered the company more recently (in 2001) and the older staff are overrepresented, it is possible that these men have responded to the company's recent incentives to work part-time, in order to combine a leisure activity or a second professional activity with their main job. Some stewards have thus developed paid activities on the side, in real estate brokerage, sports coaching or even in the hotel industry, which require a regular but not continuous presence with customers and clients, and which can be managed with flying on routes that have limited time differences. This investment in ancillary activities is probably to the detriment of their career advancement within the company, as the vast majority of CCMs in this class (91\%) have not had any promotion. That said, men in this class make up the majority of the very few flight attendants who are promoted to cabin manager.

This classification therefore makes it possible to distinguish different types of careers and to show that CCMs who do manage to make a career in this cohort are more generally childless and therefore able to be available for the company (to fly full-time, to make frequent network changes, etc.). Women work part-time much more frequently than men, on long or medium-haul flights, primarily for family reasons. This is also the case for some (very rare) men following part-time careers, on long haul flights. By contrast, the part-time careers of men on medium-haul routes seem to be due to other reasons: these childless stewards choose to invest their time in additional income-generating or leisure activities, rather than in pursuing a career in the company. Finally, we note that stewards with children are more successful than hostesses in the same situation in continuing to work full-time: in the two full-time work classes without promotions (classes 1 and 2) the average number of children is highest for men; while for women it is highest in the two classes of part-time work (classes 3 and 5). This persistence in full-time work provides stewards with higher pay, even if it does not allow them to get promoted - for the time being.

\section{Gender Rules: The New Promotion System Accentuates Inequalities between Women and Men}

The different career models and promotion opportunities, as identified in the above analysis, are linked to the rules governing advancement. 


\section{Selection Procedures and their Evolution}

The analysis of selection procedures for promotion clarifies the role of gender norms and organizational constraints in the shaping of career inequalities. Promotion to the ranks of cabin manager and chief cabin manager takes place in two phases: eligibility and admission. Initially, CCMs must meet the regulatory, eligibility conditions for promotion: they must have the required seniority; have applied by registering for the annual promotional campaigns; and have not failed any language tests or aviation safety/security tests in the twenty-four months preceding the closing date for registrations. Finally, candidates must not have received any "unfavorable opinion" from their division managers: opinions being "based on objective and precise data from candidates' professional records, including in particular in-flight assessments and instruction flights over the past two years".

Candidates whose application is declared "admissible" during the admissibility phase then undergo a day of "testing", including so-called "qualitative" tests with "in-situ simulations" and "verification of professional knowledge". A comparison of different CCM collective agreements shows that the nature and content of these tests have varied significantly over time, with the proportion of criteria aimed at assessing technical skills (level of English, safety and aviation safety tests, group simulation tests) taking up less space in comparison to tests intended to assess employees' degree of personal motivation and commitment to work. Thus, "professional group and/or individual tests" have been gradually included, as has a motivational interview conducted by a recruitment officer belonging to an external organization and by a cabin crew member (following the 2003 CCM collective agreement). During the examination of candidates' records by the joint committee in charge of promotions, ${ }^{13}$ the report produced at the end of the individual interviews is used as supporting material in a candidate's record, in which all her or his actions in the company are recorded, including, in particular: not having refused a promotion beforehand; not having been subject to disciplinary sanction; the absence of "critical absenteeism"; and not having received a negative opinion from a division head. Also included in candidates' records are all the written contributions that CCMs have been able to submit, on a voluntary basis, to sector managers, aiming for example to improve on-board service or documenting any flight incidents. These "memos" or "reports" are produced at the initiative of employees. They are not mentioned in the collective agreements covering CCMs, but they are taken into account in individual evaluations as an indicator of the knowledge of the staff's working environment, as well as an indicator of employee motivation.

These changes took place in a context in which the seniority promotion system has been partially replaced by a promotion system based on "choice", concerning $25 \%$ of the staff promoted. In 2003, this system was extended to half of all promotions. For each selection campaign held by the airline, a list of eligible candidates is thus established which includes 50\% of the positions offered according to the descending

13. The joint committee is made up of the Director of Human Resources for CCMs and union representatives. 
order of CCMs' seniority, and 50\% of the positions offered "according to the choices of the management". In other words, CCMs do not apply, but are put forward for selection by their superiors, with division managers then being responsible for examining candidates' records and defending them before the joint committee.

The data show that this new method of selection reinforces certain career inequalities. While average seniority at promotion was the same for women and men during the first period (1998-2002), during the second, promotions based on choice expanded, and men were promoted on average with less seniority than women, regardless of rank. In addition, at the rank of cabin manager, which makes up the vast majority of promotions due to the firm's job structure, the percentage of women among those promoted decreased very slightly between the two periods, in a context in which the absolute number of employee promotions fell. For 2015 alone, when the last selection for cabin managers took place in the company, detailed figures show that 45 women were promoted to cabin manager on the basis of seniority, compared to 49 men. By contrast, only 15 women were promoted to cabin manager through "choice", compared to 49 men. ${ }^{14}$ Thus, the promotion system based on choice seems to have reinforced the weight of gender norms: it accentuates the role of internal social capital within the company, which women have more difficulty in accumulating structurally.

\section{From Selection to Self-Selection}

Several filters seem to play a particularly powerful role upstream and downstream of the selection process itself. First, the self-elimination of women from selection processes is fueled by career management policies and by the rules surrounding promotion. Indeed, newly-promoted candidates are assigned to medium or long-haul routes, according to the needs of the company, and lose the possibility of flying parttime during the first year of their tenure as cabin managers. They also have no choice about geographic area of their flights. Moreover, newly-promoted staff lose seniority benefits for leave requests and scheduling arrangements. Due to this constraint, many women do not enter promotion campaigns, in order not to destabilize the often complex family organization they have managed to implement with their friends and relatives to make up for their absence when flying (LAMBERT, 2018). Recent studies (LESNARD, 2009; Pailhé, Solaz, 2009; Brousse, 2015; Villaume, Virot, 2016) have recalled that mismatches in individual and marital timetables weigh particularly on women who manage the continuity of running households, even if men appear to be more involved in parental work when mothers have atypical schedules: "the fathers mainly play a role of being [temporary] care takers of children" (BRIARD, 2017, p. 1).

Indirectly, greater competition in the airline's internal labor market, linked to the reorganizations undertaken by since 2009, seems to limit women's enrollment for promotion selection. The continued deterioration of the company's turnover since

14. The human resources department accepted to provide staff data broken down between these two forms of promotion, but only for the year 2015 . 
2005 has slowed down promotion campaigns, lengthened seniority lists and toughened competition between CCMs (a recurring subject of discussion in airplane cabins). Women seem less willing to apply for promotion, being more exposed to gendered socialization at school or at home, and so shy away from professional competition. This was clearly indicated in the interview with Valérie, 40, a long-haul hostess, holder of a BTS diploma in international trade:

"And have you passed selection to become a cabin manager or...?

- No, not at all. [...] There is clearly no room for that at the moment, as they are sacking people through voluntary redundancy plans, well, there are less places. So, on this, I have other priorities."

Moreover, women are fully aware of the role of peer co-optation, and recognize that passing technical tests is a necessary, but not sufficient, condition for promotion. They thus criticize certain informal aspects of this selection in the name of moral values they consider as superior. Émeline, 40, a hostess on long-haul routes with thirteen years of seniority, stated clearly that she values solidarity between cabin crew rather than competition, self-promotion and denunciation. She is thus representative of the way women withdraw from competition:

"There is a lot of denunciation, [by] people returning from flights: 'I'm coming back from this flight, it was great and all. But at the same time, I noticed that on this flight, the chief cabin manager, this happened, she managed the thing badly.' And bang, go on and I'll snitch on you! You don't even need to make an appointment. You go up to see your sector manager, there is always someone. And these people are then chosen on the basis of their records to become a cabin manager or chief cabin manager. It makes up record, like 'I'm involved, blah blah blah'... Our managers are quite fond of this kind of thing. Because that's the way it is: they have to find 25 hostesses among 13,000 ! That's why considering a career in all that - it's not my thing. No thanks."

(Emeline, 40, long-haul hostess, married, childless, business school graduate)

Finally, women tend to internalize the idea of their limited chances of professional success more than men do, given the context of fewer promotion campaigns. But they also reject certain aspects of the selection process. Some women who are promoted even attribute their success more to luck than to individual technical and managerial skills. This is not the case for men who have been promoted, as shown by comparing the following two extracts from interviews carried out with two cabin managers, promoted on the basis of "choice" in 2015. Marie-Pierre, 40, with a BTS as a trilingual secretary and a Bachelor's degree in applied foreign languages, joined the company at the age of 25. She was struggling in taking on her new role as cabin manager, while also keeping some distance with the careerist dimension of her promotion:

"I accepted the promotion. But it's really a fluke when you are promoted through 'choice'. I had just happened to fly with my instructor two months in a row, otherwise he wouldn't have known me. I flew with him two months in a row and we got on well. There are some people who don't see their instructor for years! But for the rest, I'm not a super hostess. I don't make a big deal [about the job]. I'm very nice to the 
people on board, yes, but I'm not here to get ahead..., I don't go down and kneel. I don't have a career plan."

(Marie-Pierre, 40, cabin manager, married with two children)

By contrast, Stéphane, a 40-year-old steward, was openly happy with his promotion. It was a goal he had set himself. He is sure of his relational and managerial skills and draws on colleagues' opinions to justify his professional success, apart from his sector manager's decision:

“I'm young and on seniority, I surely wouldn't have been promoted. So, it was only by 'choice', and therefore the choice of the management. So, my instructor had to coach me, to introduce me in Paris. And it went well. For me, in any case things have always gone very well, always. There are always people who question the choices. Why him, why not me? For me, legitimacy was never in doubt. On the contrary, people told me: 'It's normal, we are happy for you. You will be a cabin manager. You deserve it a hundred times.'

- And concretely, how did things go?

- So, the manager sees it in your investment, in your professional record, he sees you when he comes on board to see you working. So, he looks at the position you have in the team, the distance you have with the job, the way you speak, the interaction you have with customers, with the crew. He looks at all of that. In my case, she said to me: 'If there is one, it will be you.' Beforehand, I did what was necessary, that is to say I worked for my record for ten years; I invested myself in many missions for the company. I trained for five years. I participated in training courses. I am 100\% on the job. You see? As it has been a goal I wanted to achieve."

(Stéphane, 40, cabin manager, without children)

\section{"Reporting to Office": the Conditions for Accumulating Social Capital}

Analyzing the effects of the worsening economic context on the selection processes (and self-elimination) of women should not lead to ignoring the structural effects that persist and that are linked to the composition of the group of local managers - sector executives and instructors. The share of men increases going up the ranks (Table 1). Moreover, the introduction of promotion by 'choice' has reinforced the weight of local managers and co-optation by peers in the promotion process. Cécile, 54 years old, who was promoted late from hostess to cabin manager, after having suffered a first refusal of support from her superiors, points to the determinig role of her sector manager and interpersonal affinities in the chances of getting a promotion:

"In 2007, I passed the cabin manager selections. I had the necessary qualifications, but I was not chosen because my manager told me: 'We don't know you at the office; I can't pass you.' So, I said, 'Listen, I'll never pass then, because I have a life, when I get back from flights, I go home. I'm not going to hang around the office.' And I then went to see my new manager, and she got me promoted on 'choice'. She was very 
austere, very severe... I don't know, maybe, precisely, she was less into cronyism, you see. She was fair."

(Cécile, 54, cabin manager, married, one child, a Bachelor's degree in geography)

The importance of local managers thus raises the question of the conditions for accumulating relational capital within the company, which is necessary for promotion. In fact, hostesses and stewards are all the more likely to be spotted and promoted by the hierarchy if they work full time, in a sector where checks and in-flight controls are frequent. This may also partly explain the negative effects which time spent on long-haul routes has on the chances of promotion (Table 4). According to an interview carried out with a manager in the HR department, people on medium-haul routes often have the most "complete" records (containing more reports), than persons who fly longhaul: as the flights are shorter, the chances of flying with a manager are indeed greater.

But the in-flight evaluation and the proper execution of one's duties are not enough to guarantee promotion. Candidates must also provide proof of willingness to work, assessed in terms of the time worked on the one hand (limited absences, etc.), as well as their material and moral investment in the life of the company (participation in continuous training, writing memos aimed at improving the quality of service on board, volunteering to do replacements outside mandatory availability periods; for example during activity peaks at Christmas, during school holidays, etc.).

"I applied for the selections to become cabin manager. But now, there haven't been any for seven years. So, I got the marks, what was needed and all. Yet few people were admitted... and the problem is that when you're a mother, often, when a child is sick, it's the mothers who take parental sick leave [to look after the child]. In our case, I ask for them. So suddenly there are stoppages, work stoppages too. And when you're single, a single man, well... the result is that in Nice, they chose a man... I'm not making any value judgements; it's just an observation. But in fact, this is also the reality. When you're single, you have more time to devote to the company than when you have a family life... Even if you love what you do, it's more difficult."

(Noémie, 38, medium-haul hostess, married with two children)

Finally, the possibility of mobilizing "personal" time for the company, in order to do the relational work necessary for promotion, amplifies gender inequalities in a professional context in which employees live far from their airport base and do not have access to fixed office space. This situation recalls more broadly the question of employees" "biographical availability". The fact of spontaneously reporting "to one's sector" after each flight, in the offices occupied by the managers of a CCM's home division, increases the chances of being identified as a serious employee involved in the life of the company, and worthy of promotion - although the rules relating to flight service do not require this. ${ }^{15}$ The interviews show how "dropping by the office", as the expression goes, is an essentially male activity. Reporting on one's activities to colleagues and fleet managers, beyond the mandatory summons and annual interviews

15. CCMs go on board from a specific building, where they clock-in and clock-out after every flight. 
was more often done by men than women, on the basis of the interviews we conducted. Few women say they "drop by the office" when they return from their flights, even though they are familiar with this informal practice and are aware of its importance for career advancement. Women are far more likely to go directly to their cars in the airport basement car parks, without "going upstairs", so that they can pick up the children in daycare or take over from a nanny or a spouse who has been busy at home for several days.

The availability of time for work is therefore central to analyzing career dynamics. Indeed, its role in career advancement even appears to have been reinforced by the promotion rules and the socio-demographic composition of the company's sector managers, who are mainly men.

In sum, this article describes the trompe l'œil process at work when considering the gender gap between cabin crew members (CCMs) in air transport. The data on the flows of entries, exits and the stock of women and men CCMs, at different dates, show a degree of convergence in the careers of women and men over time. This has occurred concomitantly to changes in the company's economic situation and its HR policy, leading to: i) an increase in the proportion of men in hiring; ii) a convergence in the entry and exit conditions of the company, for both genders, in a context of scarce hiring and increased departures (higher entry ages, voluntary redundancy plans which become the main reason for leaving for both men and women); and iii) the expansion of part-time work for all the employees. We also observe an undeniable increase in the proportion of women in management positions, for the generations who arrived before the 2000s, or even before the 1990s. This is synonymous with a relative erosion of the glass ceiling, and it is largely explained by changes in the demographic composition of CCMs, as well as the promotion rules in force: a proportion of the many women recruited in the past automatically gained access to in-flight management positions due to seniority.

Yet the chances of promotion remain lower for women. Moreover, a change that $a$ priori is independent of equality issues between genders, such as the development of promotions based on "choice" (i.e. selection), has tended to reinforce the inequalities between women and men, despite the company's policy of supporting professional equality. The unequal "biographical availability" of women and men in fact results in different career paths, in particular as women opt for more part-time or medium-haul routes, and make investments in the company that are less favorable to promotions. Indeed, women even self-eliminate with respect to promotion procedures. While it would be wrong to say that the issue of biographical availability does not affect men's careers (see for example the different promotion speeds among men depending on their number of children), women and men do not manage the articulation between this particular job (characterized especially by nights away and atypical schedules) and 
their personal lives in the same way: a greater proportion of stewards than of hostesses remain childless, and women leave the profession more frequently by resignation than men do, fairly early in their careers. In addition, almost all women with children who remain in the profession move to part-time work, reducing their chances of promotion. This is what our analysis of career developments of a cohort of cabin crew members recruited at the turn of the 2000s has shown, along with a set of biographical interviews.

The legal requirements and injunctions concerning professional equality have therefore not made it possible to reduce significantly career differences between women and men in the company. "Gender performance" (SCHÜTZ, 2012) is said to be more favorable to the hostesses than stewards in aircraft cabins, yet actually plays a secondary role in career advancement, compared to other factors that meet the company's needs. These include accepting the strong flexibility of flight schedules linked to the cyclical nature of the airline activity, as well as accumulating relational capital with colleagues and local management.

\section{REFERENCES:}

ACKER, J. (1990). "Hierarchies, Jobs, Bodies: a Theory of Gendered Organizations." Gender and Society, (4)2, 139-158.

ALBER, A. (2013). « Un plafond de verre plus bas dans la fonction publique ? Une comparaison public/privé de l'accès des femmes aux fonctions d'encadrement. » Travail, genre et sociétés, 30, 131-154.

Allison, P. D. (1982). "Discrete-Time Methods for The Analysis of Event Histories." Sociological Methodology, 13, 61-98.

Angeloff, T., ARborio, A.-M. (2002). « Des hommes dans des "métiers de femmes": mixité au travail et espaces professionnels dévalorisés. » Sociologia del lavoro, 85, 123-135.

ANGeloff, T., LAUFER, J. (2007). «Genre et organisations. » Travail, genre et sociétés, 17, 21-25.

BARNIER, L.-M. (1997). Personnels navigants commerciaux: valorisation et dévalorisation du travail. (Mémoire de DEA de sociologie, Université Paris X - Nanterre).

BARRAUlt-STELla, L. (2014). «Former de bons représentants. Les apprentissages militants formels et informels au sein d'une association de parents d'élèves. » Les Sciences de l'éducation - Pour l'Ère nouvelle, (47)1, 95-115.

Bonanno, A. (2014). Le Temps de s'organiser. Une ethnographie des dispositions temporelles des contrôleurs/ses de train. (Mémoire de master 2, EHESS/ENS).

BoufFARTIGUE, P. (2012). « La disponibilité temporelle au travail : nouvelles formes, nouveaux enjeux. Temps de travail et travail des temps. » Colloque du CRES, Strasbourg, France: https://halshs.archives-ouvertes.fr/halshs-00731732/document, consulted January 292021.

BRIARD, K. (2017). «L'articulation des temps parental et professionnel au sein des couples: quelle place occupée par les pères? » Dares analyses, no 58. 
Brousse, C. (2015). « Travail professionnel, tâches domestiques, temps "libre" : quelques déterminants sociaux de la vie quotidienne. » Économie et statistique, 478-479-480, 119-154.

Buscatto, M., MArRy, C. (2009). «Le plafond de verre dans tous ses éclats. La féminisation des professions supérieures au Xx ${ }^{\mathrm{e}}$ siècle. » Sociologie du travail, (51)2, 170-182.

Buscatto, M., Fusulier, B. (Eds.) (2013). « Transgresser le genre au travail: des hommes dans des domaines professionnels "féminins". » Recherches sociologiques et anthropologiques, (42)2.

DeVETter, F.-X. (2006). « La disponibilité temporelle au travail des femmes : une disponibilité sans contrepartie ?» Temporalités [online], 4: https://doi.org/10.4000/temporalites.366.

DunEZAT, X. (2006). « Le traitement du genre dans l'analyse des mouvements sociaux : France/ États-Unis. » Cahiers du genre, hors-série no 1, 117-141.

Florence-AleXANDre, H., Ribeill, G. (1982). Le Personnel des compagnies aériennes. Les évolutions majeures de l'après-guerre à nos jours. Déterminants techniques et économiques. Conséquences professionnelles. Paris: Mission de la recherche, ministère des Transports.

Fremigacci, F., Gobillon, L., Meurs, D., and Roux S. (2016). «Égalité professionnelle entre les hommes et les femmes: des plafonds de verre dans la fonction publique ? »Économie et statistique, 488-489, 97-121.

Guichard-Claudic, Y. (2006). «Homme en mer, femme à terre. Petits arrangements avec la dissymétrie. » Cahiers du genre, 41, 23-47.

Guichard-Claudic, Y., Kergoat, D., and Vilbrod, A. (Eds.) (2008). L'Inversion du genre. Quand les métiers masculins se conjuguent au féminin et réciproquement. Rennes: Presses universitaires de Rennes.

Guillaume, C., Pochic, S. (2007). « La fabrication organisationnelle des dirigeants. Un regard sur le plafond de verre. » Travail, genre et sociétés, 17, 79-103.

Haicault, M. (1984). « La gestion ordinaire de la vie en deux. » Sociologie du travail, (26)3, 268-277.

Hochschild, A. R. (2017) [1983]. Le Prix des sentiments. Au cour du travail émotionnel. Paris: La Découverte.

LAMBERT, A. (2018). « Les incidences biographiques du travail mobile. Configurations familiales et rapports de genre. »L'Année sociologique, (68)2, 315-340.

LAUFER, J. (2005). « La construction du plafond de verre : le cas des femmes cadres à potentiel. » Travail et Emploi, 102, 31-44.

LESNARD, L. (2009). La Famille désarticulée. Les nouvelles contraintes de l'emploi du temps. Paris: Presses universitaires de France.

Louey, S., SchüTz, G. (2014). «Les effets de la mixité au prisme du corps et de la sexualité: les hommes dans les métiers d'accueil. » Travail et Emploi, 140, 5-19.

McAdam, D. (1986). "Recruitment to High-Risk Activism: The Case of Freedom Summer." American Journal of Sociology, (92)1, 64-90. 
McAdam, D. (2012). Freedom Summer. Luttes pour les droits civiques, Mississipi, 1964. Marseille: Agone.

MARRY, C. (2004). Les Femmes ingénieurs. Une révolution respectueuse. Paris: Belin.

Marry, C., Bereni, L., Jacquemart, A., Pochic, S., and Revillard, A. (2017). Le Plafond de verre et l'État. La construction des inégalités de genre dans la fonction publique. Malakoff: Armand Colin.

Marry, C., Jacquemard, A., Pochic, S., Bereni, L., and Revillard, A. (2015). « Le genre des administrations. La fabrication des inégalités de carrière entre hommes et femmes dans la haute fonction publique. » Revue française d'administration publique, 153, 45-68.

Mills, A. J., TAncred, P. (1992). Gendering Organizational Analysis. Newbury Park: Sage Publications.

Pailhé, A., Solaz, A. (Eds.) (2009). Entre famille et travail. Des arrangements de couples aux pratiques des employeurs. Paris: La Découverte.

Pochic, S., Peyrin, A., and Guillaume, C. (2011). « Le plafond de verre: d'une vision statique à une vision dynamique des inégalités de carrière dans les organisations. » In A. Degenne, C. Marry, S. Moulin, and Y. Grelet (Eds.). Les Catégories sociales et leurs frontières (pp. 209239). Laval: Presses de l'université de Laval.

Rodrigues, A.-C. (2010). Des femmes conductrices de poids lourds. Parcours de vie et rapport au métier d'une portion croissante de la main-d'œuvre dans un métier en mutation. (Thèse de doctorat de sociologie, Université Paris-Est).

SCHÜTZ, G. (2012). « Mobiliser par l'affect: contraintes et ressources de l'encadrement intermédiaire de prestations de services peu qualifiés. » Sociologie du travail, (54)1, 70-91.

SimÉANT, J. (2001). «Entrer, rester en humanitaire, des fondateurs de MSF, aux membres actuels des ONG médicales françaises. » Revue française de science politique, (51)1-2, 47-72.

Thompson, E. P. (2004). Temps, discipline du travail et capitalisme industriel. Paris: La Fabrique.

Villaume, S., Virot, P. (2016). « Travail à temps complet et jeunes enfants : comment font les couples pour tout concilier? «tudes et résultats, no 981.

Williams, C. L. (1992). “The Glass Escalator: Hidden Advantages for Men in the 'Female' Professions.” Social Problems, (39)3, 253-267. 


\section{APPENDIX}

FIgURE A1 - Frequency of Exits and Age at Exit by Reason for Leaving the Company for Men and Women

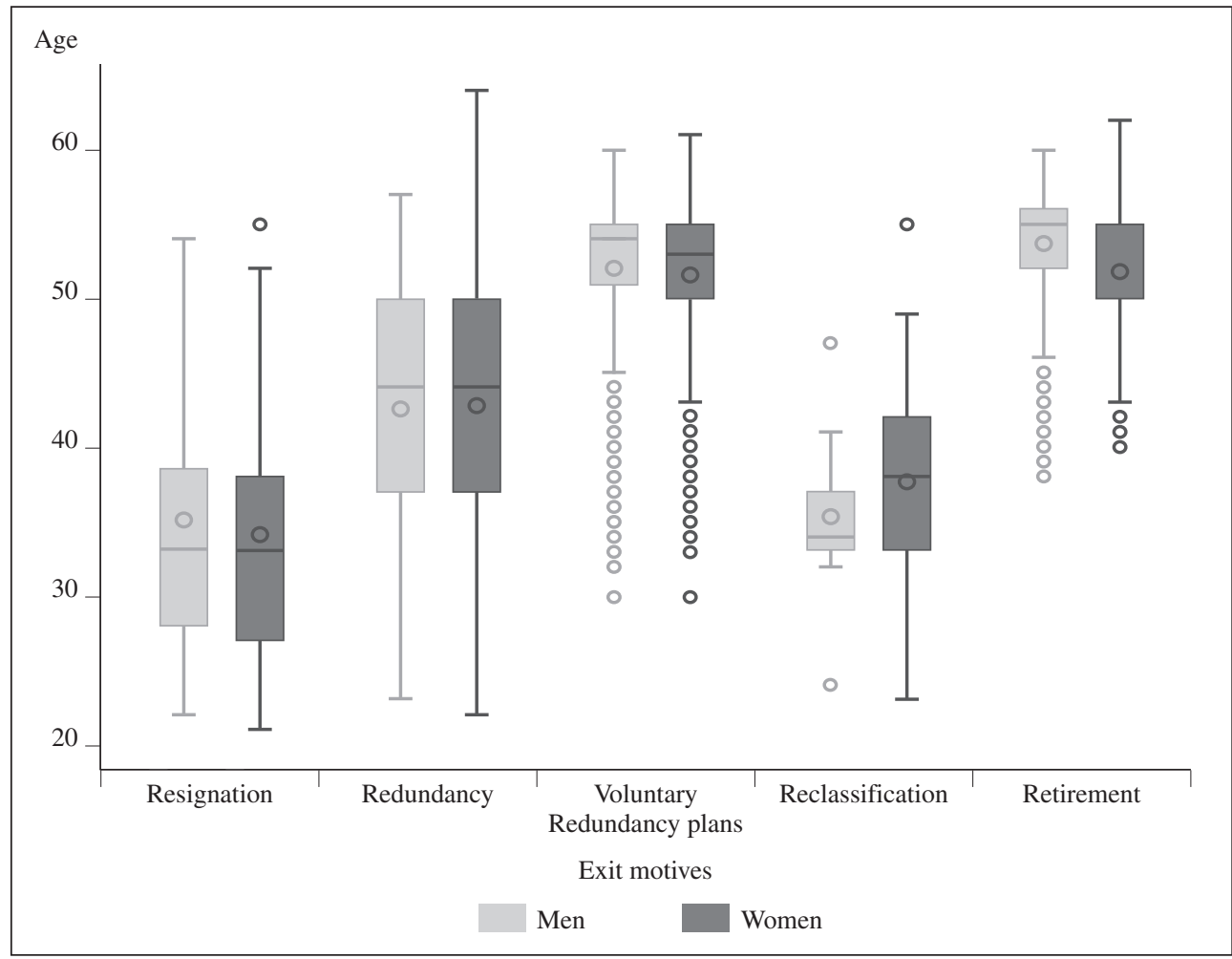

\begin{tabular}{lcc}
\cline { 2 - 3 } & Men & Women \\
\hline Exit motives (\%) & & \\
Resignation & 10 & 18 \\
Redundancy & 16 & 16 \\
Voluntary redundancy plans & 19 & 17 \\
Reclassification & 0.5 & 1 \\
Retirement & 54 & 47 \\
All motives & $\mathbf{1 0 0}$ & $\mathbf{1 0 0}$ \\
\hline Median age at exit & 53 & 50 \\
Average age at exit & 50 & 47 \\
\hline
\end{tabular}

Interpretation: Between 1998 and 2015, 1,800 men and 3,200 women quit their jobs as CCMs (excluding end of fixed-term contracts and deaths). The average age of women on exiting was 47 , and for men was 50 . The age of exit was lower for resignations than for redundancy. For resignations, the average age of leaving for women was slightly lower than for men (respectively 34 and 35 ). Field: Exiting the CCM profession, except for "death" and end of fixed-term contract, between 1998 and 2015.

Source: Company personnel records (authors' calculations). 
FIgURE A2 - Length of Time to First Promotion by Gender and Number of Children (Actuarial Method)
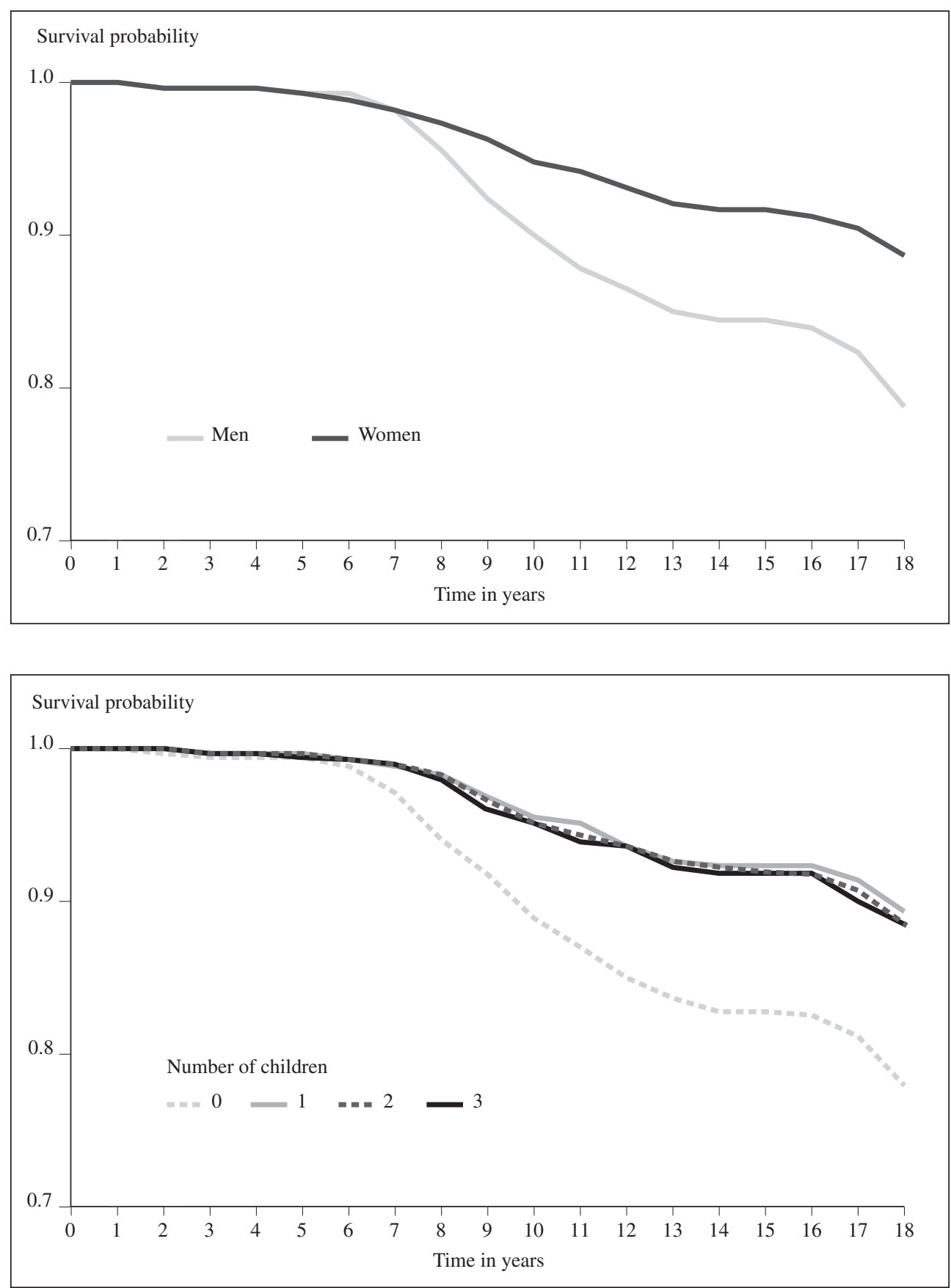

Note: To make the graphs more readable, the scale here starts at 0.7 and not at 0 .

Field: Cohort of entrants as CCMs in the company (on fixed-term contracts [CDD] or CDD that are tenured) from 1998 to 2001.

Source: Company personnel records (authors' calculations). 


\section{Men}

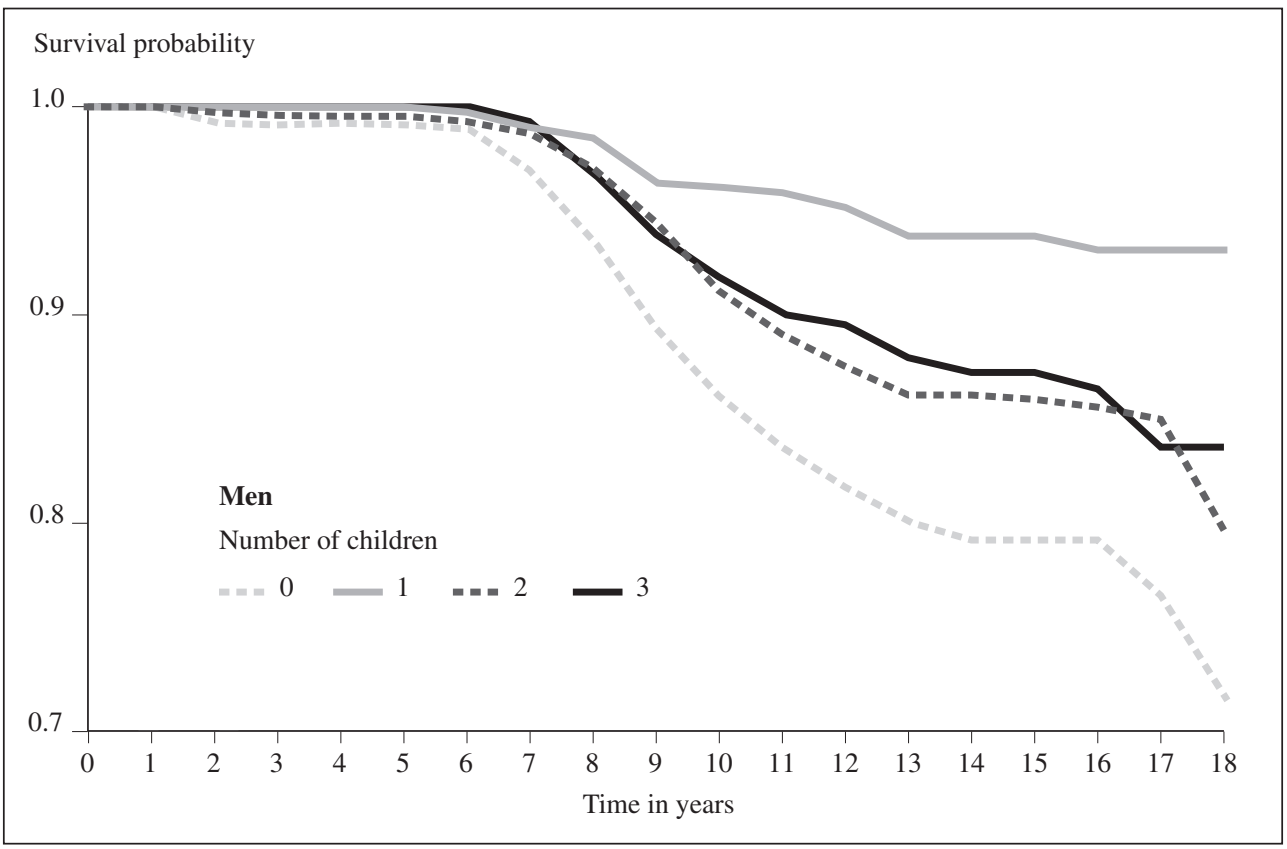

\section{Women}

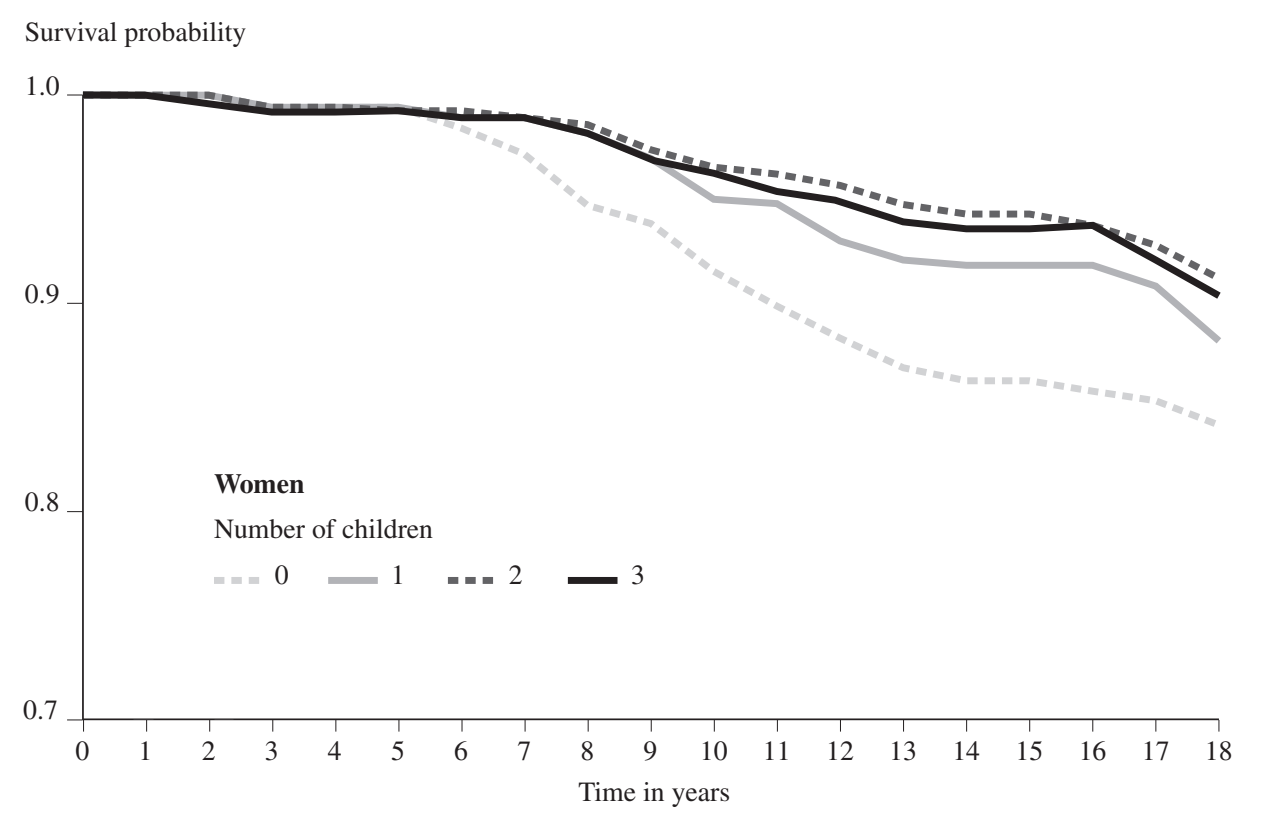

Note: To make the graphs more readable, the scale here starts at 0.7 and not at 0 .

Field: Cohort of entrants as CCMs in the company (on fixed-term contracts [CDD] or CDD that are tenured) from 1998 to 2001. Source: Company personnel records (and authors' calculations). 
TABLE A3 - Active Variables in the Career Typology

\begin{tabular}{|c|c|}
\hline Duration indicators & Indicators of number of changes \\
\hline $\begin{array}{l}\text { Duration as manager } \\
\text { Duration as cabin manager } \\
\text { Duration as chief cabin manager } \\
\text { Full time duration } \\
\text { Alternating time duration } \\
\text { Alternating part-time duration } \\
\text { Part-time duration (other than parental or alternating) } \\
\text { Duration at } 100 \% \\
\text { Duration at } 50 \% \\
\text { Duration at } 66 \% \\
\text { Duration at } 75 \% \\
\text { Duration at } 83 \% \\
\text { Duration at } 92 \% \\
\text { Duration on long-haul } \\
\text { Duration on medium-haul }\end{array}$ & $\begin{array}{l}\text { Number of changes in rank } \\
\text { Number of changes in hourly quotas } \\
\text { Number of changes of networks } \\
\text { (long/medium-haul) }\end{array}$ \\
\hline
\end{tabular}

